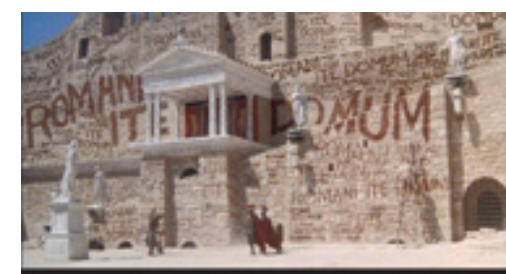

SOMETHING COMPLETELY HISTORICAL

Monty Python, History and Comedy

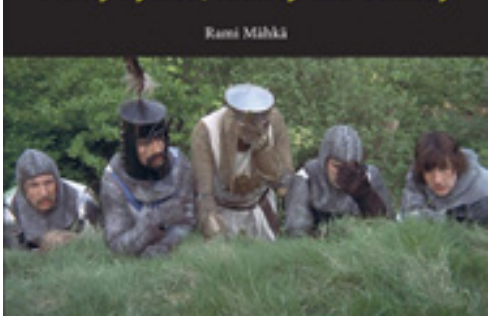

KOMEDIAN

HISTORIALLISUUDEN

MONET ULOTTUVUUDET

\author{
Rami Mähkä (2016): Something Completely Historical. Monty \\ Python, History and Comedy. Turku. 265 s.
}

Rami Mähkän kulttuurihistorian alaan kuuluva väitöskirja Something Completely Historical. Monty Python, History and Comedy kysyy, miten tunnettu brittiläis-amerikkalainen komediaryhmä käytti historiaa tuotannossaan. Historialla tarkoitetaan Mähkän tutkimuksessa paitsi mennyttä itsessään myös menneisyyden representaatioita, ovat ne sitten esimerkiksi historiallista fiktiota, yleistajuista historiankirjoitusta tai kouluhistoriaa. Ajallisesti tutkimus kulkee 1960-luvun lopun vastakulttuurista ja Pythonien Lentävä sirkus -tv-sarjasta kohti 1980-luvun thatcherismin aikaa ja ryhmän viimeisen elokuvan, The Meaning of Lifen, vaihtoehtoisen kulttuuriperinnön kommentointia.

Monty Pythonin komediaryhmä koostui viidestä brittiläisestä huippuyliopistossa koulutetusta miehestä sekä yhdestä yhdysvaltalaisesta animaattorista. Televisiosarjallaan Monty Python's Flying Circus (1969-1974) ryhmä uudisti sketsikomedian perinteitä ja toimi inspiraationa ja suunnannäyttäjänä tuleville koomikkosukupolville. Komediassaan ryhmä hyödynsi laajaa koulutus- ja sivistystaustaansa nostamalla esiin mm. filosofeja ja merkittäviä historiallisia henkilöitä ja ilmiöitä, mutta sijoittamalla nämä absurdeihin ja surrealistisiin tilanteisiin. Jättämällä vitseistään ja sketseistään pois punchlinet, Pythonit rikkoivat perinteisiä komedian malleja ja avasivat tien uusille tavoille tehdä komediaa.

Mähkä avaa tutkimuksessaan monipuolisesti niitä vaikutteita ja perinteitä, joita Monty Python hyödynsi luodessaan komediatyyliään. Tutkimuksen ensisijainen lähdeaineisto on monipuolista ja monimediaalista. Paitsi
Monty Pythonien ryhmänä tuottamat tv-sarja, elokuvat ja kirjat, ovat yksittäisten jäsenten ryhmän ulkopuoliset tuotokset ja saman aikakauden historiallis-komedialliset tuotannot tärkeässä roolissa tutkimuksessa. Oman värikkään osansa muodostavat ryhmän jäsenten muistelmat, päiväkirjat ja haastattelut. Laaja kulttuurihistoriallinen lähdeaineisto tuo tutkimukseen miellyttävää moniäänisyyttä ja korostaa kuinka brittiläisen komedian kentällä naurettiin historialle laajemminkin, vaikka Pythonit olisivat kansainvälisesti jääneet parhaiten ihmisten mieliin.

Komedian ja todellisuuden/vakavan suhde on tutkimuksen kantavia teemoja. Väitöskirjan teoreettinen pohja ja metodologiset vaateet luodaan koomisen ja ei-koomisen suhteeseen liittyvien väitteiden pohjalta. Mähkä analysoi aineistoaan monesta näkökulmasta, huomioiden sekä ensisijaisen koomisen esittämisen että ei-koomisen, historiaan kytkeytyvän kontekstin. Komedian historiallisuus tulee esille tutkimuksen kolmelle vuosikymmenelle ulottuvassa ajallisessa kontekstissa yhteiskunnallisten taustojen ja keskustelujen muuttuessa. Analyysissä Mähkä huomioi runsaan joukon komediaryhmän sketsejä, joissa pilkan kohteena on hahmoja ja henkilöitä laajalta skaalalta. Monty Pythonien komediassa kohteeksi saattoi joutua kuka tahansa taustasta riippumatta. Ryhmän tarkoituksena oli myös demokratisoida komediaa esimerkiksi suurmiehiä pilkkaamalla ja siten tiputtaen heitä alemmas heille perinteisessä historiankirjoituksessa luoduilta jalustoiltaan. 
Historiantutkijalle kiinnostavaa onkin nimenomaan historiantutkimuksen ja populaarikulttuurin suhde yhteiskunnassa ja kulttuurissa. Populaarikulttuurin esitykset ovat suurelle yleisölle merkittäviä mielikuvien luojia ja jossain määrin myös tiedon lähteitä. Suuri yleisö lukenee historiallista komediaa lähtökohtaisesti näkökulmalla "tämä ei pidä paikkaansa", mahdollisesti huomioiden oman henkilökohtaisen tietonsa ja laajemman yhteiskunnallisen ja kulttuurisen keskustelun luomat mielikuvat menneisyydestä. Historiallisen draaman osalta taas ei välttämättä näin ole. Mähkän tutkimusta lukiessa aloin pohtia, millaisilla keinoilla historiallisissa draamoissa menneisyys esitetään ja millaisin keinoin niissä kenties pyritään vakuuttamaan katsoja menneisyyden kuvauksen aitoudesta - samaan tapaan kuin Monty Python pyrki komediallaan purkamaan mielikuvia ja asettamaan historiallisen kuvauksen käytänteet ja historialliseen tietoon suhtautumisen kyseenalaisiksi. Tarkoitusperät sekä draamassa että komediassa ovat kuitenkin usein samat: historian elävöittäminen. Mähkän analyysissa nousee näitä elävöittämisen tapoja runsaasti esiin.

Väitöskirja jakautuu neljään käsittelylukuun, joissa avataan monipuolisesti eri konteksteja, joita vasten Monty Pythonien komediaa voi lukea. Mähkä pohtii aluksi Monty Pythonin komedian vastakulttuurisuutta ja avaa heidän tv-sarjansa tapaa luoda komediaa televisiosta mediana. Komedian itseviittaava luonne nousee Lentävän sirkuksen sketseissä vahvasti esiin, kun Pythonit parodioivat television sarjoja ja genrejä ja paljastavat television konventioita tehdäkseen komediaa televisiota varten. Parodiointi kohdistuu myös sarjaa tuottaneeseen BBC:hen, ja sarjan esittäminen arvostetulla, perinteikkäällä kanavalla liittää Pythonit osaksi sitä Establishmentia, jota he sarjassaan pilkkaavat. He testasivat rajoja, mitä valtakunnallisella tv-kanavalla voi esittää ja millaisin seurauksin.

Parodioidessaan historiallista fiktiota Pythonit muistuttavat katsojaa jatkuvasti, että ruudulla nähdään elokuva, ei todellisuutta. Monty Pythonien elokuvissa luoma maailma ei ole erityisen koherentti tai lineaarisesti etenevä, ja ryhmä rikkoo tarkoituksellisesti fiktioelokuvan rajoja tuomalla mukaan esimerkiksi dokumentaarisia keinoja ja jo tv-sarjastaan tuttuja tapahtumien keskeytyksiä ja tilanteesta poikkeavia hahmoja. Mähkä pohtii toisessa käsittelyluvussa parodioinnin eri muotoja tarkastelemalla komediaa vastaelokuvana, heikentämällä historiallisen spektaakkelin loistoa esimerkiksi juuri vastaelokuvallisin keinoin sekä tarkastelemalla Pythonien komediaa osana varietee-perinnettä ja sitä parodioiden. Luku avaa tutkimuksessa selkeimmin niitä monimuotoisia audiovisuaalisia keinoja, joita Pythonit historiallista komediaa tehdessään käyttivät.

Kolmannessa käsittelyluvussa Mähkä pohtii komedian ajallista ja tilallista joustavuutta ja vapautta käsitellä historiallista tietoa. Komedian luonne mahdollistaa sellaistenkin teemojen käsittelyn, joihin valtavirran historiallinen elokuva ei tarttuisi. Monty Python trivialisoi historian suurmiehiä, esittää historiallista tietoa anakronistisesti ja kyseenalaistaa keskiaikaan liittyviä mielikuvia farssin keinoin. $\mathrm{He}$ haastavat perinteistä valtavirran historiankirjoitusta ja -näkemystä purkamalla esitystapoja ja -käytänteitä. Mähkä löytääkin tästä kiinnostavaa yhteneväisyyttä Pythonien komedian ja postmodernin välillä.

Historiallisia aikakausia, joihin Pythonit komediassaan runsaasti viittaavat ja jotka Mähkä nostaa analyysinsä kohteeksi, ovat keskiaika, brittiläisen imperiumin aika ja toinen maailmansota. Viimeksi mainittuun liittyy sodan pitkä ajallinen perintö sekä yhteiskunnallinen ja kulttuurinen läsnäolo kylmän sodan aikaisessa maailmassa. Tietynlainen kyllästyminen sodasta puhumiseen ja sen käsittelemiseen toimi sodan aikana tai pian sen jälkeen syntyneille Python-jäsenille polttoaineena tehdä komediaa hyvin synkästä aiheesta ja trivialisoida sotaa ja sen merkityksiä. Heidän komediassaan nousee esille sukupolvikonflikti; keskiluokkaistaustaiset Pythonit sopeutuivat 1960-luvun vastakulttuuriin ja ilmensivät sitä töillään.

Neljännessä käsittelyluvussa Mähkä avaa Pythonien tapaa käsitellä toisen maailmansodan aikaa ja imperialistista menneisyyttä. Luvun kiinnostavinta antia löytyy viimeisestä käsittelyluvusta, joka tuo ajallisen käsittelyn 1980-luvulle ja thatcherismin aikaan. Mähkä pohtii Pythonien viimeistä elokuvaa The Meaning of Life osana 1980-luvun alun 
kulttuurikeskustelua, jossa menneisyys ja historia olivat runsaassa hyötykäytössä. Brittiläiseen elokuvaan syntynyt käsite heritage film (perinne-elokuva) nosti esiin menneisyyden kuvauksia 1800-luvun lopulta ensimmäisen maailmansodan vuosiin asti korostaen usein ylempien yhteiskuntaluokkien elämää samalla mennyttä nostalgisoiden. Perinne-elokuvat nostivat esiin monia brittiläisen yhteiskunnan perinteikkäiksi miellettäviä ja kansainväliselle yleisöllekin populaarikulttuurista ja kirjallisuudesta tuttuja ilmiöitä, kuten sisäoppilaitokset, aristokraattisen dekadenttiuden ja upseeriston yläluokkaisen elämän. Komediat ovat jääneet perinne-elokuvakeskusteluissa syrjään, mutta Mähkä pohtii tapoja lukea The Meaning of Lifea perinnekeskustelun varjossa: Pythonit kuvaavat esimerkiksi Margaret Thatcherinkin puheissa kaivattuja "vanhoja hyviä aikoja" ironisen nostalgian kautta.

Rami Mähkän väitöskirjan eduksi on sanottava, että vaikka hän analysoi joitain Pythonien hauskimpia sketsejä hyvinkin tarkasti, ei syväluotaava analyysi onnistu vähentämään huumorin voimaa. Päinvastoin, itse Pythonfanina koin valaistumisen hetkiä ymmärtäessäni entistä paremmin, mihin asioihin joillain sketseillä tai komedian keinoilla Pythonit viittaavat. Epäkoherenttien, äkillisesti päättyvien ja keskenään sekoittuvien sketsien lähiluku ei varmastikaan ole ollut helppoa, mutta Mähkä onnistuu tutkimuksessaan sanallistamaan audiovisuaalisen aineiston selkeästi. Väitöstilaisuuden aikoihin omakustanteena ilmestyneen väitöskirjan soisi päätyvän laajempaan jakeluun kustantajalle, ja Monty Pythonien suosion ja aiheen luonteen vuoksi myös kevyempi ja populaarimpi tietokirja olisi mukava ilmestys.

\section{Elina Karvo}

FM, kulttuurihistoria, Turun yliopisto 